SAND95-1554

Unlimited Release

UC-1272

\title{
Manufacturing Injection-Molded Fresnel Lens Parquets for Point-Focus Concentrating Photovoltaic Systems
}

Eric M. Peters and Jon D. Masso

AOtec

14 Mechanic St.

Southbridge, MA 01550

Prepared by Sandla National Laboratories Albuquerque, New Mexico 87185 and Livermore, California 94550 for the United States Department of Energy under Contract DE-AC04-94AL85000

Printed October 1995

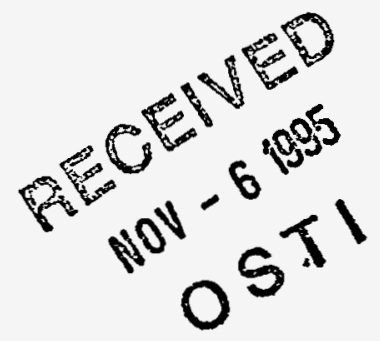


Issued by Sandia National Laboratories, operated for the United States Department of Energy by Sandia Corporation.

NOTICE: This report was prepared as an account of wotk sponsored by an agency of the United States Government. Neither the United States Government nor any agency thereof, nor any of their employees, nor any of their contractors, subcontractors, or their employees, makes any warranty, express or implied, or assumes any legal liability or responsibility for the accuracy, completeness, or usefulness of any information, apparatus, product, or process disclosed, or represents that its use would not infringe privately owned rights. Reference herein to any specific commercial product, process, or service by trade name, trademark, manufacturer, or otherwise, does not necessarily constitute or imply its endorsement, recommendation, or favoring by the United States Government, any agency thereof or any of their contractors or subcontractors. The views and opinions expressed herein do not necessarily state or reflect those of the United States Government, any agency thereof or any of their contractors.

Printed in the United States of America. This report has been reproduced directly from the best available copy.

Available to DOE and DOE contractors from

Office of Scientific and Technical Information

PO BOX 62

Oak Ridge, TN 37831

Prices available from (615) 576-8401, FTS 626-8401

Available to the public from

National Technical Information Service

US Department of Commerce

5285 Port Royal Rd

Springfield, VA 22161

NTIS price codes

Printed copy: A04

Microfiche copy: AOJ 
SAND95-1554

Unlimited Release

Printed October 1995

\title{
Manufacturing Injection-Molded Fresnel Lens Parquets for Point-Focus Concentrating Photovoltaic Systems
}

\author{
Eric M. Peters and Jon D. Masso \\ AOtec \\ 14 Mechanic St. \\ Southbridge, MA 01550
}

Sandia Contract 23-7089

\begin{abstract}
This project involved the manufacturing of curved-faceted, injection-molded, fourelement Fresnel lens parquets for concentrating photovoltaic arrays. Previous efforts showed that high-efficiency (greater than $82 \%$ ) Fresnel concentrators could be injection molded. This report encompasses the mold design, molding, and physical testing of a four-lens parquet for a solar photovoltaic concentrator system.
\end{abstract}




\section{Acknowledgments}

The authors would like to thank all the AOtec staff members who contributed to this effort during the course of the contract including Clark Grendol, Arlene Philla and Ray Davis.

The authors would also like to recognize the technical assistance and testing provided by the staff at Sandia National Laboratories especially C.B. Stillwell and J.R. Woodworth.

The authors would also like to thank the subcontractors who assisted on this program; Precision Optical Corporation of Gardner MA. Diamond Electro-Optics of Marlboro MA, and TRW Fasteners Division of Westminister MA. Special mention must also be given to the superb work in performed at TRW by Paul Courtemache and Roger Pompei. 


\section{Contents}

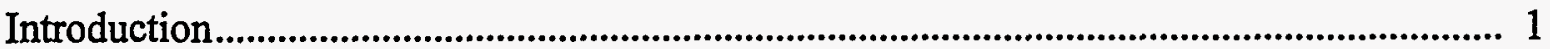

Mold Design.................................................................................................................................. 1

Optical Design .................................................................................................................... 3

Construction and Testing of Optical Inserts .....................................................................15

Molding of the 4-Lens Parquet ..................................................................................................19

Parquet Testing ..............................................................................................................................19

Conclusions...................................................................................................................20

Recommendation for Future Work ....................................................................................21

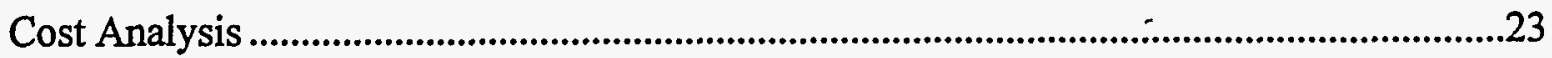

Appendix I, List of Subvenders and Codevelopers...............................................................26

\section{Figures}

Part Diagram for Single-Cavity Fresnel Lens............................................................................ 2

Part Diagram for 4 Fresnel Lens Array ................................................................................. 4

Photograph of "A" Mold Half..................................................................................................... 5

Diagram of "A" Mold Half ...................................................................................................... 6

A-Side of 4-Fresnel Lens Parquet.......................................................................................... 7

Photograph of "A" and " $B$ " Halves of Mold ........................................................................... 8

Diagram of Solar Concentrator Assembly ..................................................................................10

Diagram of Facet Numbering and Dimensioning.....................................................................13

Spot Diagrams for Fresnel Lens Design ................................................................................14

Tables

Average Calculated Transmission for 5 Optical Designs ........................................................11

Data for Option One Curved Faceted Design ............................................................................12

Initial Measurements of Lens Efficiencies.............................................................................17

Efficiencies of Lenses in the Parquet..........................................................................................18

Fresnel Solar Concentrator Price Calculations ........................................................................25 


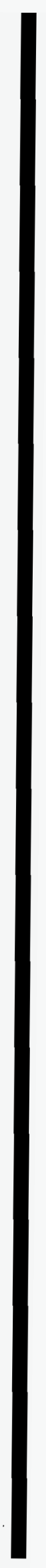




\section{Introduction}

This final report provides a summary of technical efforts performed under a development contract with Sandia National Laboratories on the "Development of an Injection Molded Fresnel Lens Parquet for Point Focus Concentrating Photo Voltaic Systems". (Sandia Contract No. 23-7089).

This contract was a continuation of the development started under Sandia Contract No. 52-7481, "Design and Development of Injection Molded Fresnel Lenses for Point Focus Photovoltaic Systems".

The objective of this contract was to take the information gained from the initial contract and construct a Fresnel lens parquet. Each lens in the parquet was to have efficiency greater than $80 \%$ and concentrate the light evenly on $\sim 1$ sq. cm area photovoltaic cell.

Fresnel lens parquets are currently produced by compression molding. This process is less cost effective in most instances than injection molding. Development of an injection molding process with higher yields and lower labour content could reduce the cost of a concentrator and ultimately the cost of electricity produced by photovoltaics.

A number of lessons were learned during the initial Sandia contract. Initially, attempts were made to mold Fresnel lenses with a large number of facets over the area and small relief for each facet (Sandia Baseline Module II design, SBM II). - During injection molding the valleys and peaks of the facets were not completely filled resulting in much lower efficiencies ( $68 \%$ ) than those obtained by compression molding of similar Fresnel lenses or from theoretical calculations (82\%). Analysis and design calculations resulted in a new Fresnel design (Sandia Baseline Module IV, SBM IV) with only 17 facets and 0.120 in. of relief. Mold inserts for this new design were constructed. Molded lenses had an efficiency of $\sim 82 \%$ compared with the theoretical value of $87 \%$.

Molding tests with the SBM IV insert indicated that complete filling of even these relatively large facets was a difficult process. Small deviations in the filling of the facets reduced the Fresnel lens efficiency drastically. To achieve the near theoretical performance nearly perfect optical mold inserts were constructed and vacuum was applied to the mold to reduce the air trapped at the facet tips as the mold cavity filled with plastic. Diamond turning marks on the facets adversely affected the efficiency of the lens. Diamond turning and post polishing techniques were developed by the contractor, Rank Pneumo of Keene N.H.(now a part of Optical Filter Corp.), to reduce the scattering caused by the turning marks.

\section{2) Mold design}

The design of the 4 Fresnel Lens parquet mold was based on the development work for the single cavity mold done in the earlier contract. The single cavity design took a number of parameters into consideration including, polymer melt flow, birefringence, shrinkage, uniform heating and cooling of inserts and part warpage.

The parts are center gated to reduce warpage, distortion of the surfaces and aid in the filling of the parts (see Figure 2.1). Part warpage is often caused by the alignment of 


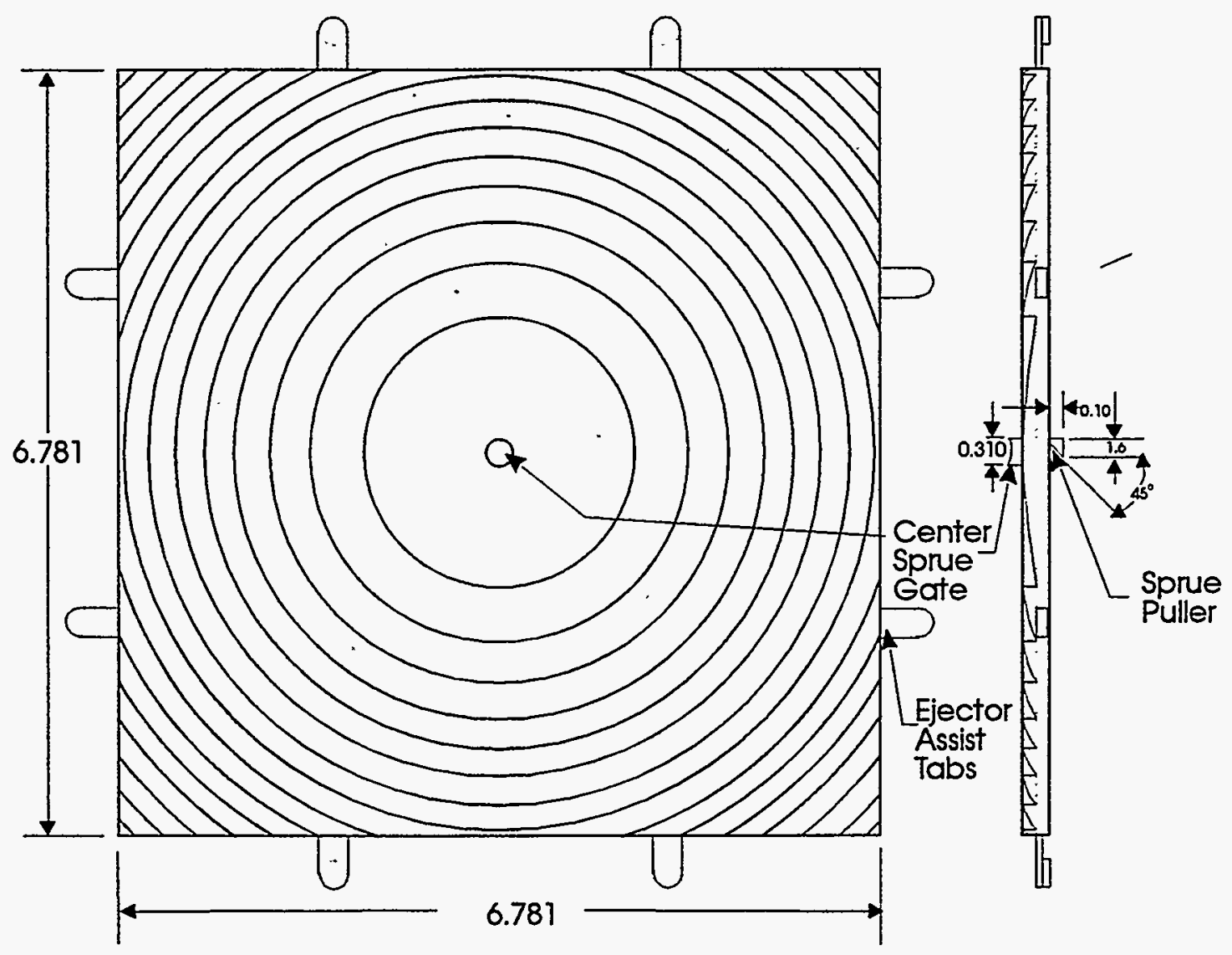

Figare 2.1 Part Diagram for Single Cavity Fresnel Lens (dimensions are in inches) 
polymer molecules within the part. The polymer molecules are aligned in the direction the flow of the polymer resin during the injection of the polymer into the cavity. Shrinkage of a single polymer molecule as it cools is normally anisotropic. The shrinkage is normally larger in the direction along the polymer chain axis than between polymer chain segments. A flat part, gated at one edge, tends to curl toward the gate due to the orientation of the polymer chains with the flow across the part from the gate. Center gating provides more even flow through the lens and minimizes the distance the polymer resin must flow from the gate, reducing the amount of flow orientation, the risk of flow lines and as a result warpage of the part.

Ejector tabs were attached to the edge of the single cavity part to assist the sprue puller in pulling the part evenly from the Fresnel lens insert in the mold and to aid in the ejection of the part from the flat lens insert (see Figure 2.1). The parquet does not have similar tabs (See Figure 2.2). The four sprue pullers evenly pull the parquet from the Fresnel insert in the mold. Ejection from the flat (B side) insert is assisted by the 16 ejection pins along the outer $0.75^{\prime \prime}$ flange of the parquet (see Figure 2.2 and Figure 2.3).

The center gating of each Fresnel element in the parquet required sophisticated hot sprues and a distribution manifold to distribute the resin evenly to each sprue/gate. This system was supplied by Incoe and was installed in the mold by the mold maker TRW (see Figure 2.4).

An elaborate system of heating/cooling lines in the mold provided even heat transfer to the optical inserts and ultimately the parts (see Figure 2.5). Figure 2.5 shows the system of heating/cooling channels for the "A"(sprue side) half of the mold. These channels are $~ 1.75 \mathrm{in}$. behind the optical inserts. The "B" side (ejector side) contains a similar system of channels. The thermal conductivity of stainless steel, used to make the insert, is less than normal D2 tool steel and other materials used for mold inserts. To compensate, the optical inserts were kept relatively thin $(\sim 1.25 \mathrm{in}$.) allowing the channels to be close behind the insert in the second mold plate. The second mold plate or support plate was relatively thick ( 3 in.) to reduce the risk of insert warpage.

Large support pillars (2.5" diameter) were placed behind the support plates on the " $A$ " and "B" sides to prevent any distortion of the support plates and transfer loads to the backing plates (see Figure 2.6). Ten pillars were required to support the area removed for the placement of the Incoe hot runner system. Fourteen pillars in the "B" side accommodated the ejector system.

As stated before, it was difficult to fill the fine points of the Fresnel facets in the initial work. This problem was corrected by the addition of a mold vacuum system which drew the air from the mold prior to the injection of plastic. A delay was added to the injection cycle to allow the system to evacuate the air from the mold cavity. A similar system was added to the 4 cavity mold which required the addition of a seal around the mold cavity and plumbing to attach the vacuum system (see Figure 2.6).

\section{3) Optical Design - Curved Faceted Fresnel Lenses}

The initial curved faceted Fresnel lens designed, constructed and molded in the previous contract (Sandia Contract No. 52-7481) was not fully optimized. Before the 4 


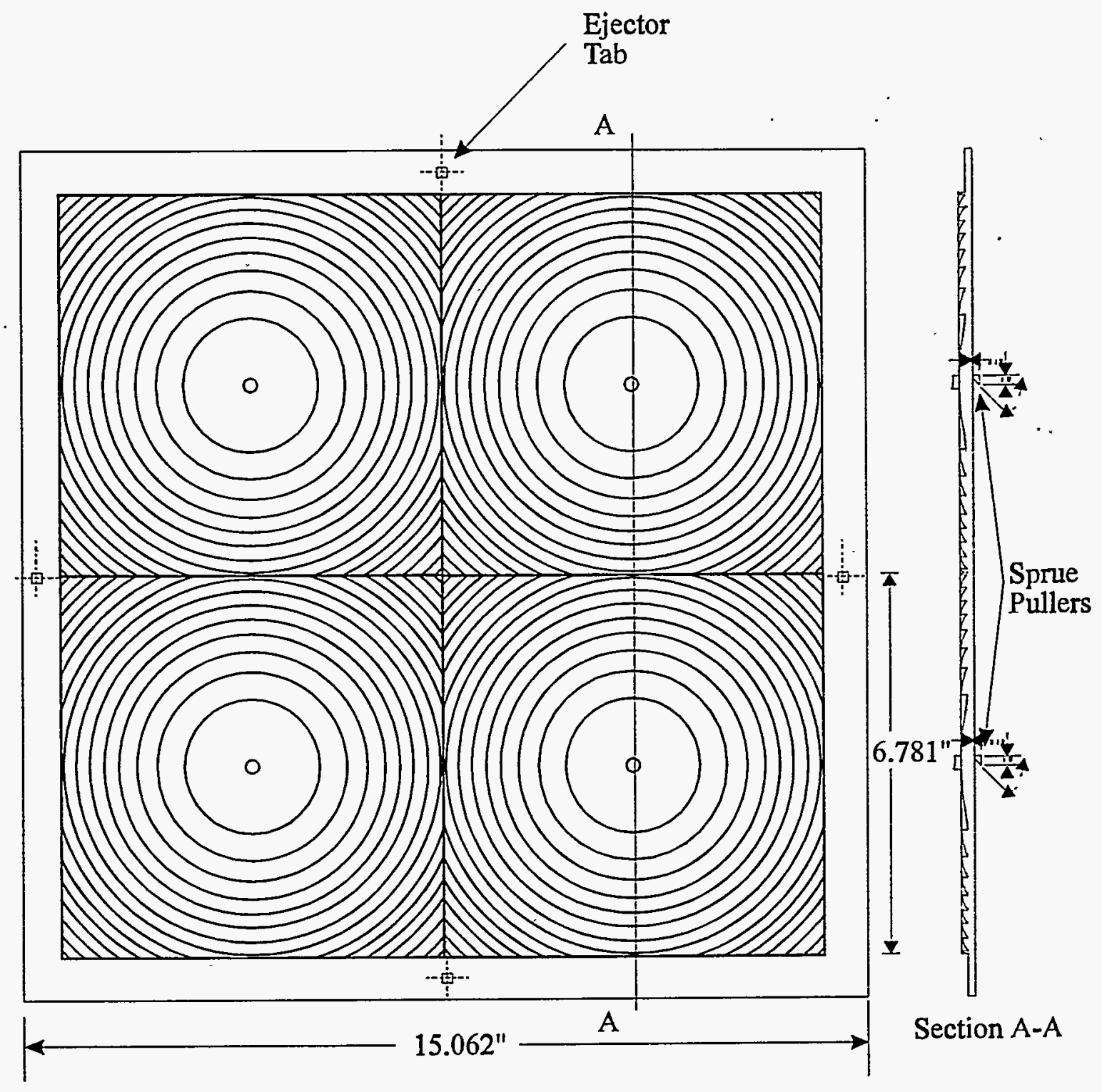

Figure 2.2 Part Diagram for 4 Fresnel Lens Array (dimensions in inches) 


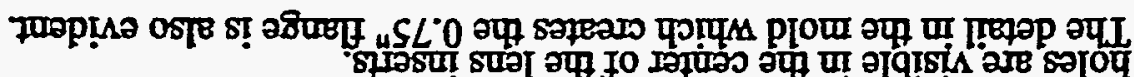

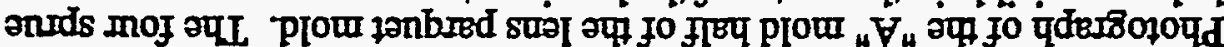

Ecom8tx

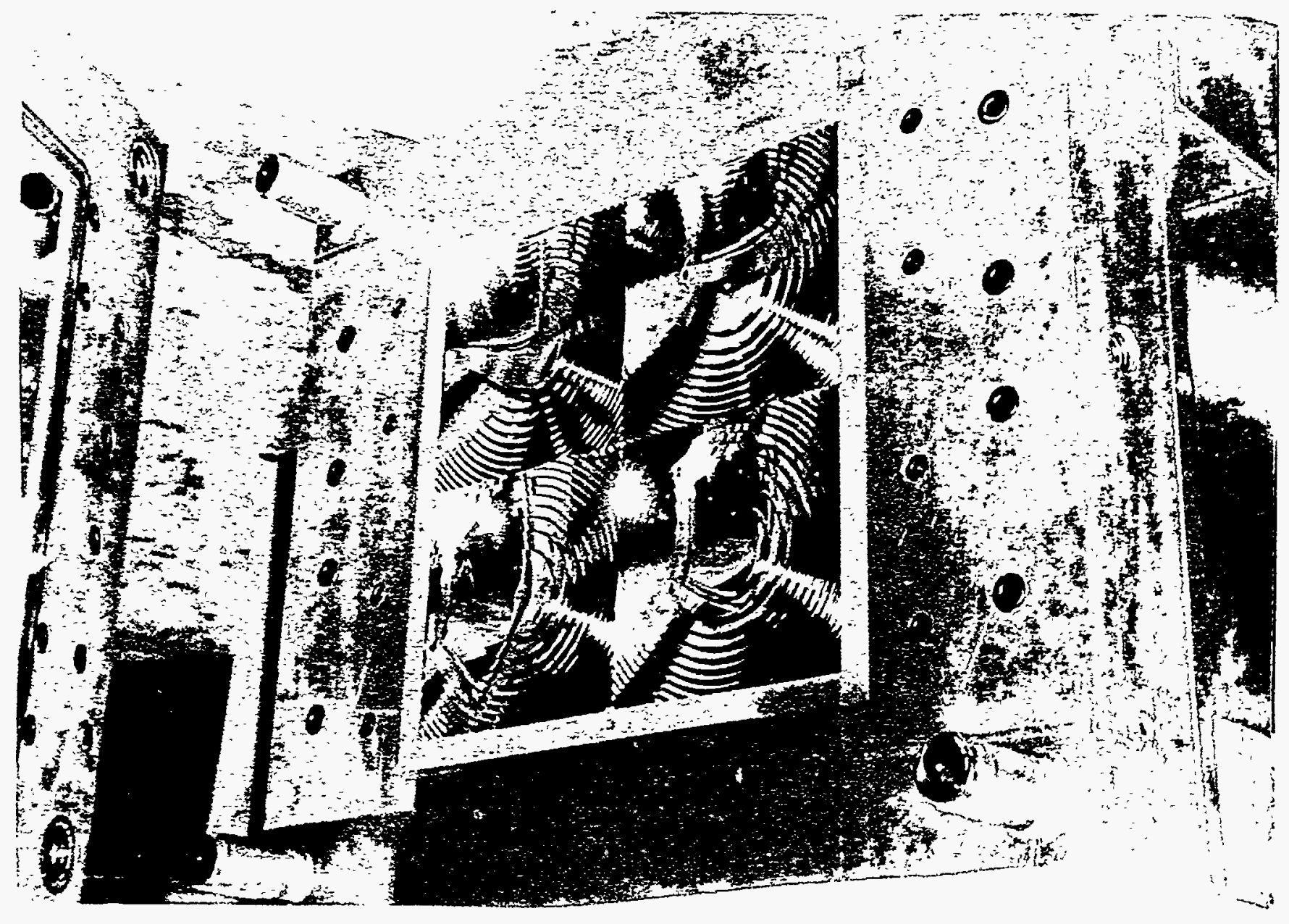




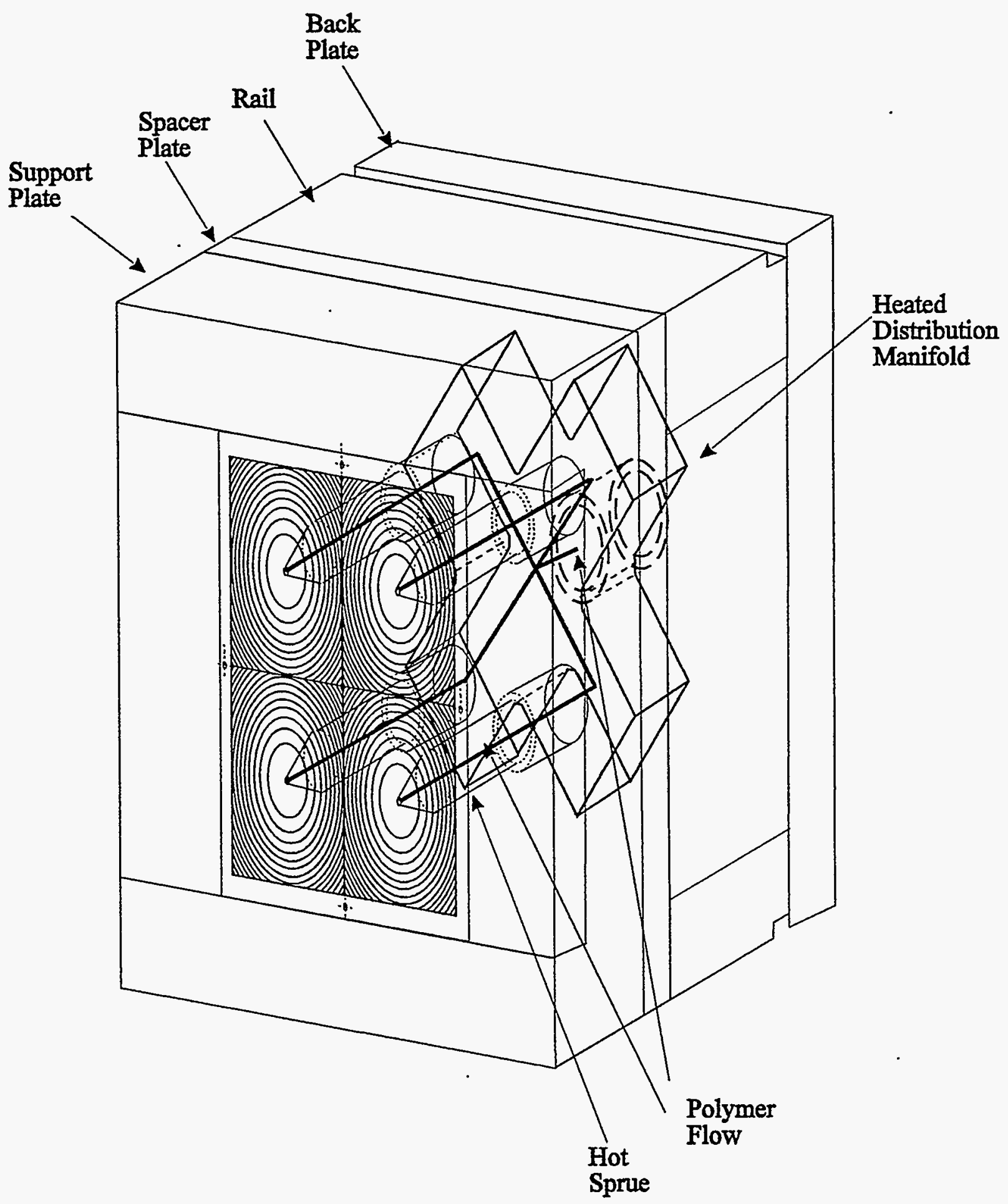

Figure 2.4 Diagram of the " $\mathrm{A}$ ' half of the 4 Fresnel Lens Parquet Injection Mold Diagram highlights the Inoe Hot Runner Hot Tip System. Water Cooling lines and wiring for the manifold and hot tips are not shown 


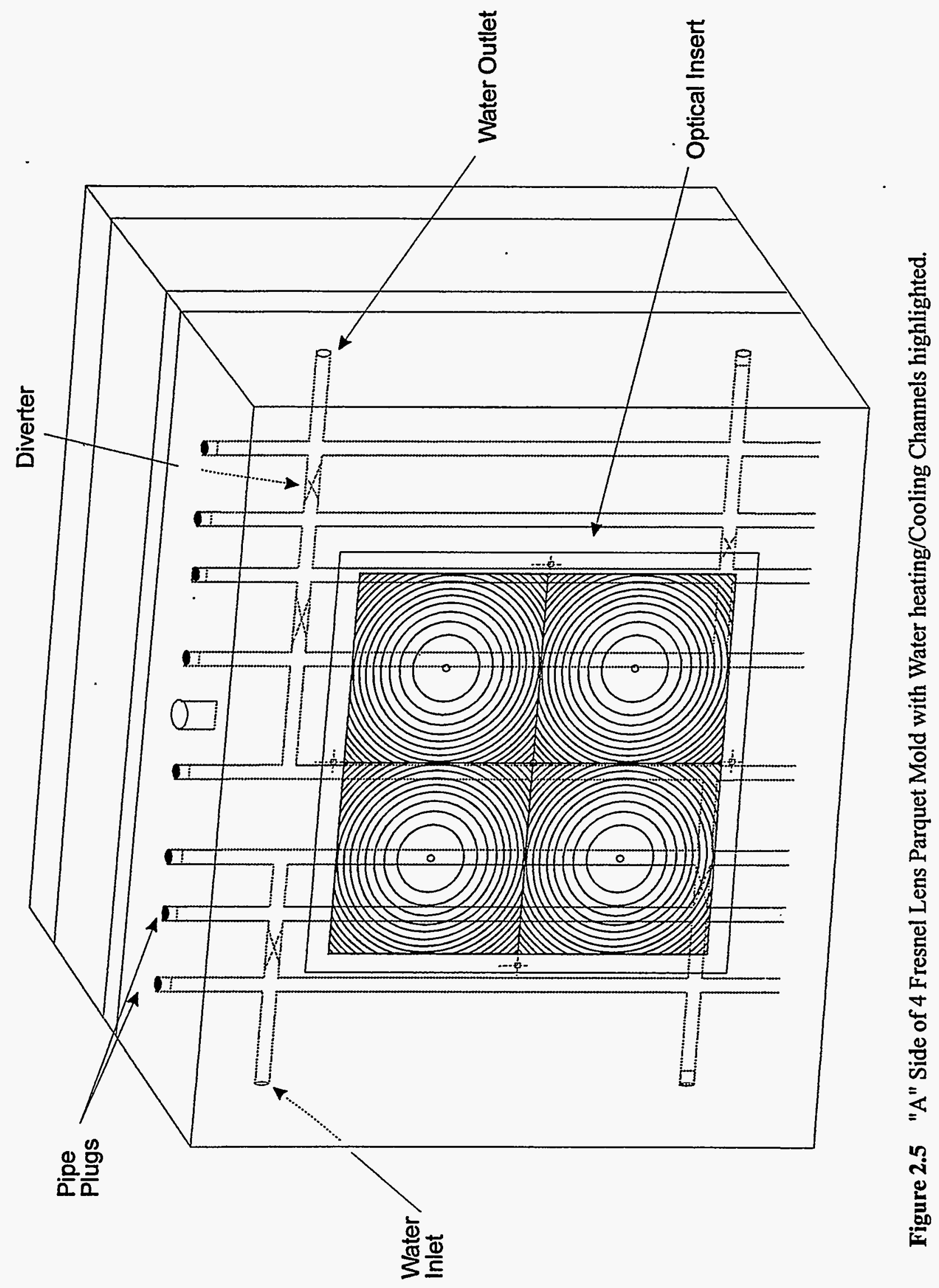




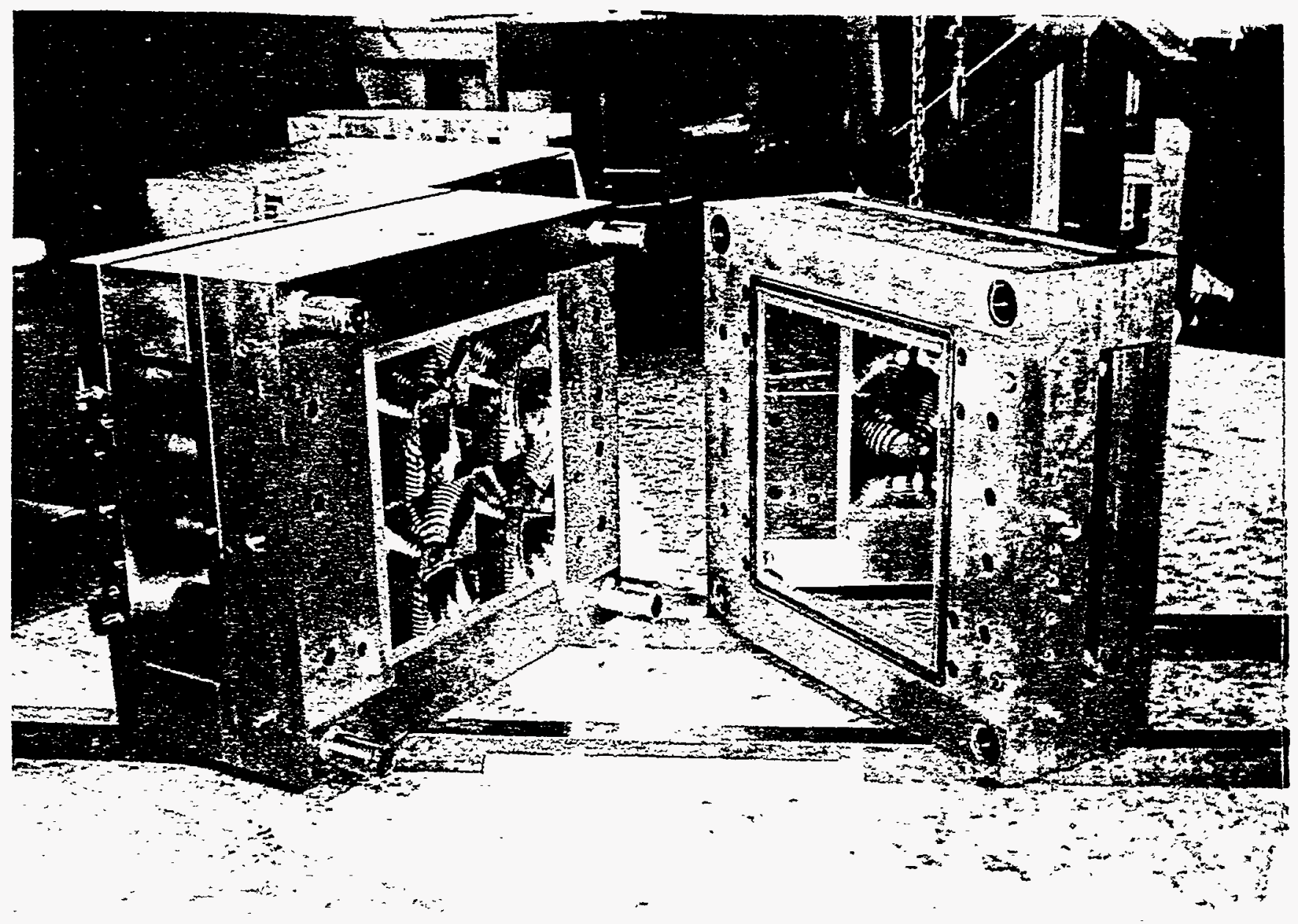

"A" Half

"B"Half

Figure 2.6 Photograph of the " $A$ "and " $B$ " mold halves of the lens parquet mold. The vacuum gasket is visible on the "B" half of the mold as a thin black line circling the insert.

The support pillars are visible on the side of the " $A^{n}$. half of the mold. 
inserts were diamond turned for the parquet the design was further refined. The initial design was developed using software developed by L.W. James Associates of Ft. Collins, Colorado. Precision Optics Corporation of Gardener MA was subcontracted to study the initial design and improve on it, if possible. AOtec provided them the software (CgSqSec Solar Software) which had been purchased from L.W. James Associates.

The initial criteria for the optical design were set by the previous work and from specifications set by Sandia National Laboratories. The parquet was designed to fit into a fixture such as the one diagrammed in Figure 3.1. The lens to photovoltaic cell distance, photovoltaic cell area and the dimension for the Fresnel lenses were determined from the concentrator module specifications.

The design parameters are as follows:

1. Lens Size:

2. Solar cell Size:

3. Lens to Solar cell Spacing

4. Total Lens Thickness

5. Facet Depth

6. Facet Draft Angle

7. Facet Tip Radii

8. Facet Valley Radii

9. Sprue Diameter

10. Resin Material
6.82 inches square (later reduced to 6.78 )

0.394 inches square

10 inches

0.245 inches

0.120 inches

1 degree

0.0015 inches

0.001 inches

0.250 inches (later increased to 0.310 )

Poly (methylmethacrylate) (PMMA)

The objectives were to design a lens with $\sim 300 \mathrm{X}$ concentration and as even a distribution of energy across the solar cell as possible. The central region of the solar cell was to receive slightly less energy than the outer area. This would accommodate any warpage in the lens over time which would tend to cup the lens and concentrate the energy more in the center. A square reflective type secondary optical element (SOE) (not diagrammed in Figure 3.1) was also planned for the concentrator. This element reflected light back onto the photovoltaic cell and partially compensated for tracking errors of the concentrator array. The fringes of the concentrated spot of light which fell outside the solar cell area would also be partially recovered by the SOE. This reflected light was also considered by the designers in the overall optical design, but the SOE was not redesigned to minimize the light loss.

The main tasks left to the designers considering the specifications and the initial design criteria, were the aiming of the individual lens facets to concentrate the light evenly on the photovoltaic cell and minimize the losses from SOE reflections. The L.W. James, $\mathrm{CgSqSec}$ Solar Software's code was modified to aid in the aiming of the facets.

Five design options were presented to AOtec by Precision Optics Corp. All the designs had theoretical efficiencies close to 87 percent. Option 1 was recommended as it minimized the energy losses due to metal absorption by the SOE (see Table 3.1). Note that on Table 3.1 the losses due to metal absorption are somewhat proportional to, the intensity of the light at the edge of the photovoltaic cell (the $\mathrm{H}$ height values). Designers 


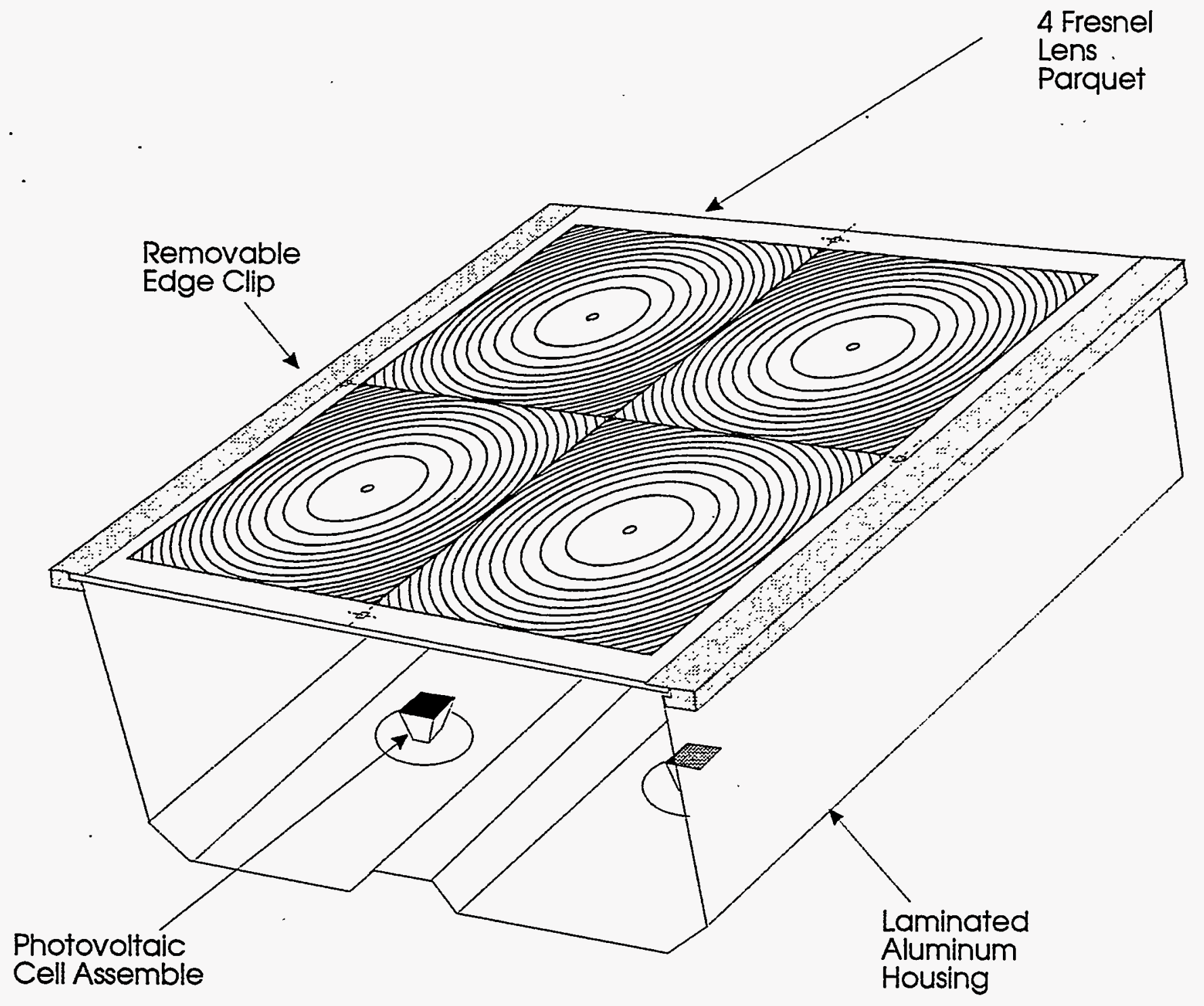

Figure 3.1 Diagram of Fresnel Photovoltaic Concentrator Assembly. 
Table 3.1 Average Calculated Transmission (Theoretical Efficiency) for 5 Optical designs. Note: $\mathrm{H}$ height is the peak intensity of the light at the edge of the photovoltaic cell. Values are given as ratios versus the best design, Option 1 .

\begin{tabular}{|l|c|c|c|}
\hline \multicolumn{1}{|c|}{ Design } & $\begin{array}{c}\text { Average } \\
\text { Transmission } \\
\text { (to Cell) }\end{array}$ & $\begin{array}{c}\text { Metal } \\
\text { Absorption } \\
\text { (by SOE) }\end{array}$ & H-height \\
\hline Option 1 & 0.8722 & 0.0122 & 1.00 \\
Option 1 (sharp) & 0.8802 & 0.0119 & 1.00 \\
Option 2 & 0.8695 & 0.0142 & 1.09 \\
Option 3 & 0.8694 & 0.0154 & 1.18 \\
Option 4 & 0.8678 & 0.0162 & 1.22 \\
Option 5 & 0.8668 & 0.0180 & 1.30 \\
\hline
\end{tabular}


Table 3.2 Data for Option 1 Curved Faceted Design where; $R$ is the radius from the center of the lens (see Figure 3.2), $\mathrm{H}$ is the height of the facets measured from the peak of the facets on the insert (valleys on the lens), $R$ ' is the radius of curvature of the facets and $q$ the angle at the inside edge of the curve as shown in Figure 3.2.

\begin{tabular}{|c|c|c|c|c|c|c|}
\hline \multirow{2}{*}{$\begin{array}{l}\text { Facet } \\
\text { No. }\end{array}$} & \multicolumn{2}{|c|}{ Facet Peaks } & \multicolumn{2}{|c|}{ Facet Valleys } & \multirow{2}{*}{$\begin{array}{c}\text { R' } \\
\text { Radius of } \\
\text { Curvature }\end{array}$} & \multirow{2}{*}{$\begin{array}{l}\theta \text { Angle at } \\
\text { Inside Edge }\end{array}$} \\
\hline & $\mathbf{R}$ & $\mathbf{H}$ & $\mathbf{R}$ & $\mathbf{H}$ & & \\
\hline 1 & 0.00000000 & 0.120 & 0.15500000 & 0.120 & Flat & 0.000000000 \\
\hline 2 & 0.12500000 & 0.120 & 1.20071173 & 0.000 & 4.88148221 & 0.000000000 \\
\hline 3 & 1.20530634 & 0.120 & 1.68193014 & 0.000 & 5.46249738 & 11.55318440 \\
\hline 4 & 1.68652475 & 0.120 & 2.04951793 & 0.000 & 6.27995085 & 16.54878650 \\
\hline 5 & 2.05411253 & 0.120 & 2.35818914 & 0.000 & 7.27082754 & 20.24792069 \\
\hline 6 & 2.36278374 & 0.120 & 2.63350831 & 0.000 & 8.29621411 & 22.88292987 \\
\hline 7 & 2.63810291 & 0.120 & 2.88558498 & 0.000 & 9.43224551 & 25.03259610 \\
\hline 8 & 2.89017958 & 0.120 & 3.12037172 & 0.000 & 10.68879244 & 26.83742247 \\
\hline 9 & 3.12496633 & 0.120 & 3.33969595 & 0.000 & 12.33059024 & 28.62679532 \\
\hline 10 & 3.34429055 & 0.120 & 3.54861128 & 0.000 & 13.88989613 & 29.93750180 \\
\hline 11 & 3.55320589 & 0.120 & 3.75201097 & 0.000 & 14.93913402 & 30.67013766 \\
\hline 12 & 3.75660558 & 0.120 & 3.94772585 & 0.000 & 16.76853145 & 31.73821714 \\
\hline 13 & 3.95232046 & 0.120 & 4.13652450 & 0.000 & 18.93096386 & 32.74960529 \\
\hline 14 & 4.14111911 & 0.120 & 4.32088291 & 0.000 & 20.68567767 & 33.42546781 \\
\hline 15 & 4.32547752 & 0.120 & 4.50130144 & 0.000 & 22.57071640 & 34.04338814 \\
\hline 16 & 4.50589604 & 0.120 & 4.67882599 & 0.000 & 24.20850295 & 34.50856847 \\
\hline 17 & 4.68342060 & 0.120 & 4.84952660 & 0.000 & 29.27422040 & 35.64495066 \\
\hline
\end{tabular}



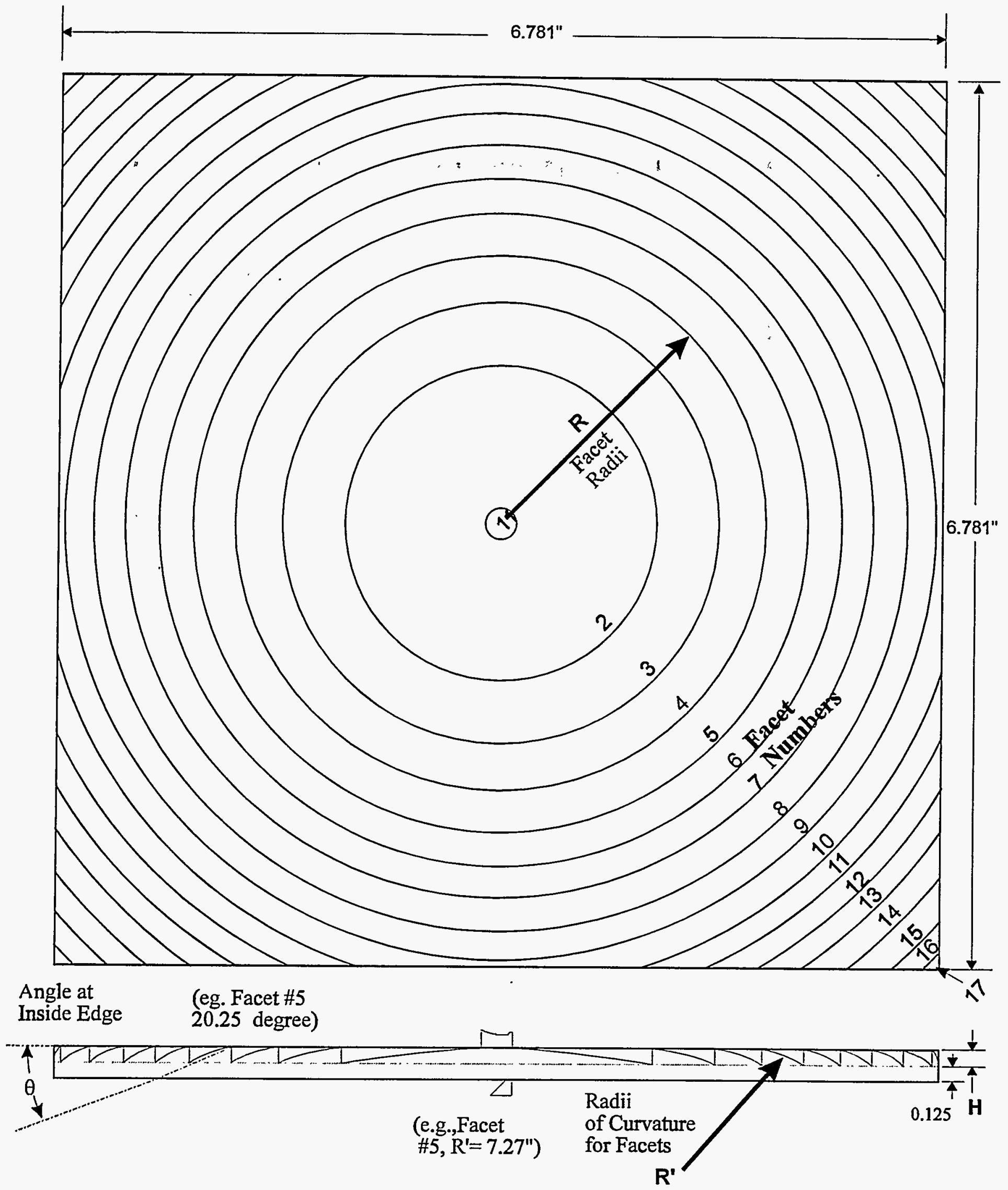

Figure 3.2 Diagram of the Facet Numbering and Dimensioning System used in the Lens Design 


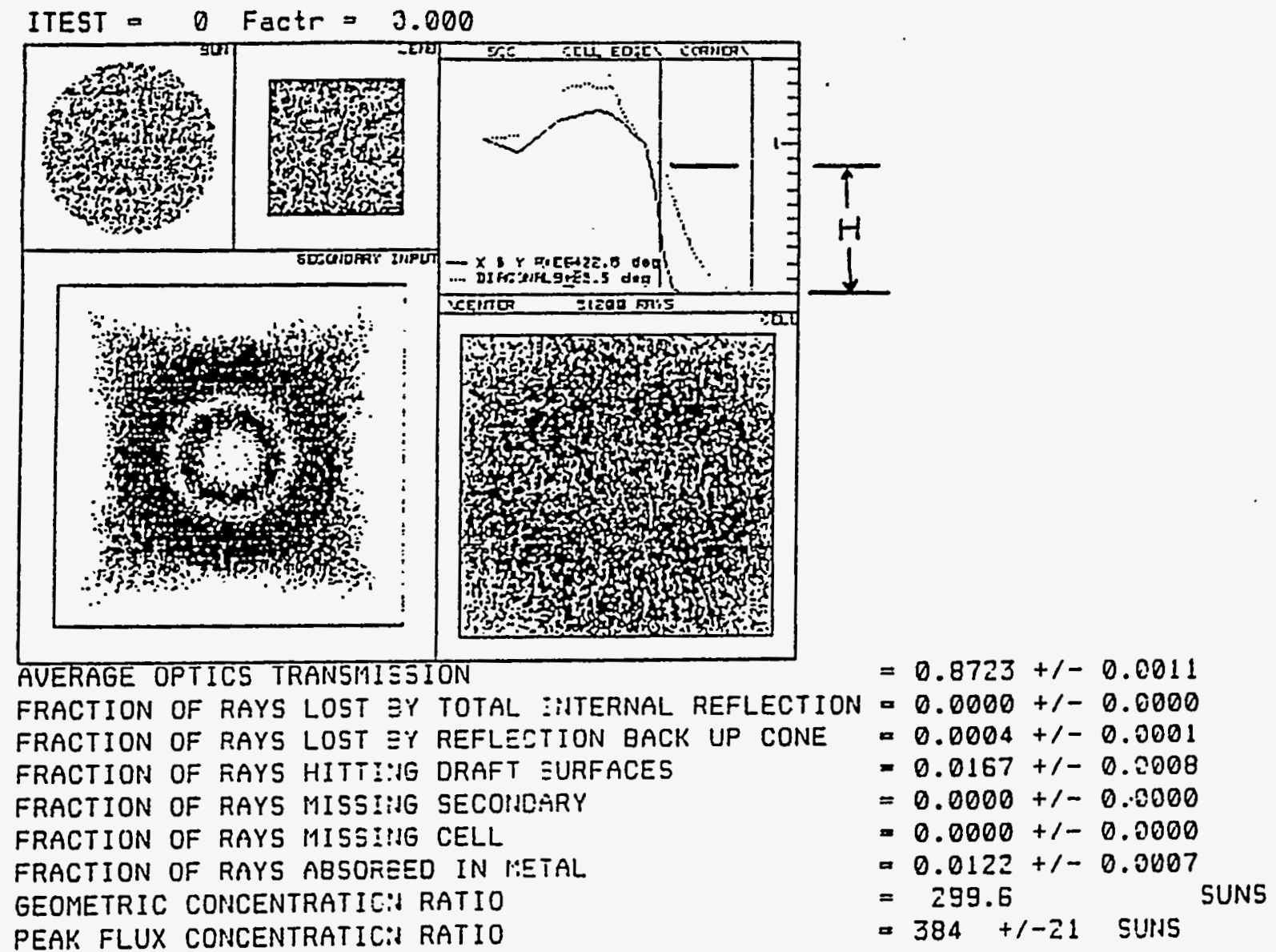

Figure 3.3 Spot Diagrams for Fresnel Lens Design

Spot diagrams representing rays of light through planes of the sun (upper left), the Fresnel lens (upper center), the secondary cone input plane (focal plane, lower left) and the photovoltaic solar cell (lower right). 
found that the distribution of light outside the photovoltaic cell area was reflected in the $\mathrm{H}$ height value for the designs attempted. A sharp transition between the lighted cell area and the darkened $\mathrm{SOE}$ at the edge of the cell was not possible to due to design objectives and constraints placed on the Fresnel lens.

The dimensions for the Option 1 design which was used for the 4 lens parquet inserts are listed in Table 3.2. The methods for dimensioning the facets are diagrammed in Figure 3.2. The center facet is listed as flat. This area is machined flat to remove the sprue/gate after the part is molded. Figure 3.2 shows the part as molded prior to this operation.

Designs were also compared using spot diagrams and line diagrams such as those shown for Option 1 in Figure 3.3. The four spot diagrams represent the location of a ray of light on four different surfaces, the sun, lens, secondary cone input plane and the photovoltaic solar cell. A single ray of light passing from the source (sun) through the Fresnel lens to the focal plane is shown as a single dot on the four diagrams. A uniform gray pattern indicates an even distribution of energy over the surface in question. Note that the distribution of light over the Fresnel lens and the sun are modeled as uniform distributions. The spot diagram for the light at the SOE input plane is nonuniform with very little energy falling in the center and another band further out. Once the light reaches the photovoltaic solar cell the energy is much more evenly distributed with only a slight depression of intensity in the center of the cell and near the edges and corners. The line diagram shows the energy distribution as a function of radial distance and indicates uniform distribution over most of the cell and a slight decrease in energy at the center of the photovoltaic cell.

The coordinate measurements were calculated for the option 1 design. A PMMA lens was machined as a test lens and was used as a gauge to check Fresnel mold inserts as they were machined and after completion. The efficiency of this lens was tested before the optical inserts were machined.

\section{4) Construction and Testing of Optical Inserts.}

The optical inserts were constructed using a similar technique to the one developed in the previous Sandia contract. Stainless steel inserts were cut using a computer controlled lathe, plated using electrodeless nickel plating, fine finished using a computer controlled diamond turning lathe and then post polished to soften the pattern from the diamond turning.

Unfortunately the company that developed this process in the initial contract (Rank Pneumo of Keene NH.) was unable to machine the additional four inserts for the 4 lens parquet mold. Although the process appears relatively simple on paper it is difficult to control. Many diamond turning companies do not have control of the plating process which is contracted to a plating company. This is a critical step in the process. Most plating companies are not accustomed to consistently plating metals to the quality required. Defects in the plated metal such as pin holes and voids do not normally appear until after diamond turning or post polishing is completed. Problems with the plating 
adhesion or defects do not appear until after parts have been molded with the tool. This delay in the detection of problems adds to difficulty in controlling the plating process.

Although diamond turned inserts are thoroughly inspected by the contractor and by AOtec upon receipt, defects in the post polishing are difficult to find on the polished surface by visual inspection. The inserts must be mounted in the injection mold and optical parts produced for inspection to qualify an insert.

Preparation of the diamond, centering, aligning, diamond tool speed and other factors related to the turning operation are critical to the production of a good insert. Each turning machine operates slightly differently and requires an expert technician who is completely familiar with the machine to operate efficiently and produce high quality results.

The company which was initially contracted to diamond turn the 4 Fresnel lens inserts was Diamond Electro-Optics of Wilmington MA.

Diamond Electro-Optics delivered 4 inserts at intervals which are labeled 1 through 4 in Table 4.1. The inserts were inspected and then placed in the one cavity mold and parts were produced for evaluation. Data from initial tests on the parts from each insert were relayed back to Diamond Electro-Optics. These are also in Table 4.1. The techniques used by Rank for the SBM2 insert are compared to those used by Diamond Electro-Optics on Table 4.1.

The initial insert (1) was not post polished and the lenses had low efficiency. Note that different tool speeds and diamond diameters were used compared to the Rank turnings. The insert was returned to Diamond Electro-Optics for polishing. The same techniques were used on the second except that it was post polished. The efficiency increased but was still less than $80 \%$. The post polishing process was improved for the third insert and the efficiency increased to slightly over $80 \%$ but was still less than the SBM2 insert completed at Rank. Small pits in the electroplated nickel are evident in the facet tips and roots of this insert which lower the efficiency. For the fourth insert Diamond Electro-Optics attempted to duplicate the speed and conditions used by Rank. The efficiency of the Fresnel lens produced was lower than lens 2 and 3 using the Diamond Electro-Optics turning conditions. Inserts 2 and 4 were returned for reworking to achieve greater efficiency.

Apart from the technical problems encountered in the diamond turning process Diamond Electro-Optics was sold, moved to Marlboro MA and renamed Contravis in 1990-1991. New Management in 1993 renamed the operation New England Diamond Turning. The changes in the personnel which occurred due to the changes in management, location, etc., delayed the process of correcting the inserts and increased the propensity for errors. All 4 corrected inserts were not received and accepted until the spring of 1992, 31/2 years after the original delivery dates. Some of the inserts were reworked more than once to achieve the desired results. After all the inserts were received, molded, tested and approved, the inserts were assembled into the parquet mold and the lens parquets were molded. Results of the final efficiency testing are given in the Table 4.2. Insert numbers given for these tests correspond to their position in the assembled parquet as shown in Diagram 4.1. These numbers are not related to those assigned for the earlier results given in Table 4.1. 
Table 4.1 Initial Measurements of lens efficiencies for lenses molded on parquet inserts. Measurements made at Sandia National Laboratory. Data from review November 22, 1989.

\begin{tabular}{|l|l|l|l|l|l|}
\hline & SBM2 & Insert 1 & Insert 2 & Insert 3 & Insert 4 \\
\hline $\begin{array}{l}\text { Efficiency } \\
\text { (measured over } \\
\text { O.495 sq. in.) }\end{array}$ & $81.6 \%$ & $64.4 \%$ & $77.9 \%$ & $80.7 \%$ & $71.1 \%$ \\
$\begin{array}{l}\text { Facet Face } \\
\begin{array}{l}\text { Tool Feed Speed } \\
\text { (in. per rev.) } \\
\text { Diamond Radii }\end{array}\end{array}$ & 0.00014 & 0.00028 & 0.00028 & 0.00028 & 0.00014 \\
$\begin{array}{l}\text { Facet Root/Radii } \\
\text { Tool Feed Speed (in. } \\
\text { per rev.) } \\
\text { Diamond Radii }\end{array}$ & 0.00014 & 0.00028 & 0.00028 & 0.00028 & $0.00014 "$ \\
Note: & $0.0005^{\prime \prime}$ & $0.001 "$ & $0.001 "$ & $0.001 "$ & $0.001^{\prime \prime}$ \\
& & $0.0001^{\prime \prime}$ & $\begin{array}{l}0.00 \\
\text { Post } \\
\text { Polished }\end{array}$ & $\begin{array}{l}\text { Improved } \\
\text { Post } \\
\text { Polishing }\end{array}$ & $\begin{array}{l}\text { Initial } \\
\text { SBM2 } \\
\text { Conditions }\end{array}$ \\
\hline
\end{tabular}


Table 4.2 Efficiencies of Lenses in the Parquet. Measurements taken at Sandia National Lab., Lens Analyzer 11/92 program, Data 6\&7 of 11/92.

\begin{tabular}{|c|c|c|c|c|c|c|}
\hline $\begin{array}{c}\text { Lens/ } \\
\text {-Parquet } \\
\text { No. }\end{array}$ & $\begin{array}{l}\text { Lens to } \\
\text { cell } \\
\text { Spacing } \\
\text { (inch) }\end{array}$ & $\begin{array}{c}\text { Efficiency } \\
\left(1.00 \mathrm{~cm}^{2}-\right. \\
0.394 \text { in sq. } \\
\text { Area })\end{array}$ & $\begin{array}{c}\text { Efficiency } \\
\left(1.08 \mathrm{~cm}^{2}-\right. \\
0.425 \text { in. } \\
\text { sq. Area) }\end{array}$ & $\begin{array}{c}\text { Efficiency } \\
\left(1.6 \mathrm{~cm}^{2}-\right. \\
0.630 \text { in. } \\
\text { sq. Area })\end{array}$ & $\begin{array}{c}\text { Maximum } \\
\text { Concentration } \\
\text { (in Suns) }\end{array}$ & $\begin{array}{c}\text { Average } \\
\text { Concentration } \\
\left(1.00 \mathrm{~cm}^{2} \text { in }\right. \\
\text { Suns })\end{array}$ \\
\hline \multirow{3}{*}{1} & 9.9 & 75.5 & 78.4 & 85 & 364 & 229 \\
\hline & 10.0 & 80.5 & 81.7 & 85 & 438 & 243 \\
\hline & 10.1 & 82.6 & - & 85 & 743 & 251 \\
\hline \multirow{3}{*}{2} & 9.9 & 78.3 & 81.4 & 88 & 386 & 238 \\
\hline & 10.0 & 83.2 & 85.0 & 88 & 434 & 254 \\
\hline & 10.1 & 84.8 & 85.8 & 88 & 801 & 257 \\
\hline \multirow{3}{*}{3} & 9.9 & 80.1 & 83.4 & 88 & 382 & 243 \\
\hline & 10.0 & 82.4 & 84.2 & 88 & 450 & 250 \\
\hline & 10.1 & 85.6 & 86.6 & 88 & 763 & 260 \\
\hline \multirow{3}{*}{4} & 9.9 & 78.6 & 80 & 87 & 362 & 233 \\
\hline & 10.0 & 83.2 & 85 & 89 & 466 & 252 \\
\hline & 10.1 & 86.0 & 87 & 89 & 737 & 261 \\
\hline
\end{tabular}


Table 4.2 shows that all four inserts produced lenses with efficiency values greater than $80 \%$. The average efficiency was $82.3 \%$ at the specified area of $1.0 \mathrm{~cm}$ square and spacing of 10 inches. However, the efficiencies of the lenses from Insert 1 (Insert 3 in Table 4.1) were considerably lower than the others. Ideally all the lenses should have had efficiencies greater than $82 \%$ and approaching the theoretical $87 \%$. However Insert 1 was not repolished after the initial work by Diamond Electro-Optics as it was slightly greater than the required $80 \%$. With slightly larger solar cells the efficiencies did approach or exceed the theoretical value. This indicates that some of the rays of light were slightly misaligned from the solar cell area specified $(1.0 \mathrm{~cm}$ square), but were not scattered or reflected over larger areas. Slight imperfections in the surface finish of the inserts or warpage of the parts may account for the scattering of the rays.

\section{5) Molding of the 4 lens parquet.}

After the lenses from the 4 inserts had been molded in the single cavity mold and tested for optical efficiency, the inserts were assembled in the 4 lens parquet mold. The mold was mounted in a 1000 ton HPM press. The Incoe heat controller and Mold-VAC 2000 mold vacuum system were attached. The ICI PMMA CP-82 was placed in the hopper dryer and parts were molded.

Part cycle times were 72 seconds. Filling the part required 25 seconds with a 25 second hold time and a 22 second cooling time. Injection pressures were approximately $900 \mathrm{lb}$.

After removal from the mold each lens parquet was placed on a special cooling plate so that the part remained as flat as possible and did not warp during cooling.

The mold was run for 2, 8 hour days. Most of the first day of running involved the purging of the molding machine and the set up of the Incoe heating manifold/hot tip by the factory representative. The second day process parameters were explored and good parts were molded for testing. Since the large mold and molding machine required considerable time to reach equilibrium molding conditions, approximately 5 hours of process time was possible before the mold was removed on the second day.

The Incoe hot runner system was still not set up correctly on the second day of running. Some of the gates drooled plastic after the removal of the part indicating that the tip shut offs were not functioning correctly. Incoe was contacted and the service technician was prepared to be present at the next running of the mold.

The best parquets molded from the second day of production were sent to Sandia National Laboratory for testing.

A second molding was scheduled but the molding never was completed.

\section{6) Parquet Testing}

The lens parquets from the second day of operation were sent from AOtec to Sandia for evaluation. Some of the lenses had small blemishes in the center of the lens due to the fact that the Incoe Hot tips did not shut the gates correctly. The lens parquets were measured for efficiency at Sandia. Some of the results are listed in Table 4.2. 
In addition to the efficiency testing some environmental tests were performed on the lens parquets. Parquets were mounted in the Solar Kinetics Inc. (SKI) concentrator assembly (see Figure 3.1 ) and thermally cycled between -40 and $60^{\circ} \mathrm{C}$ for a number of cycles. No deformation or cracking of the lens parquets occurred.

The lens parquets were subjected to the Hail Ball Test. In this test 1 " ice balls are propelled at the lens parquet at $23 \mathrm{~m} / \mathrm{s}(52 \mathrm{mph})$. The projectiles strike the front surface of the lens array. The array was held in the SKI concentrator unit and mounted against a solid support. In both cases the array cracked in the center of the array near the intersection of the four Fresnel lenses. The cracks were within the first few facets of the Fresnel lenses confined to the central 2 to 2.5 inches of the array.

After the Hail Ball tests were completed options to increase the strength of the array were considered. Acrylic resins having greater impact resistance were considered as replacements to the ICI CP-82. Impact modified PMMA such as Autohaas's Plexiglass ${ }^{\top \mathrm{M}}$ resins normally have other polymers or PMMA copolymers blended into the PMMA to increase impact resistance. However these other resins are not always completely compatible with the PMMA and therefore tend to increase the haze in the molded part. The decreased transmission of light caused by the haze would decrease the efficiency of the collectors negating the care given to the design and molding of the array.

CP-82 was chosen for its excellent mold release characteristics. After examining the available impact modified resins no acceptable resin was identified to replace the CP82.

\section{7) Conclusions}

The initial objective of producing an injection molded Fresnel lens array with efficiencies greater than $80 \%$ for a solar photovoltaic concentrator was achieved. One lens had a slightly lower efficiency than that of the other lenses, but all were greater than $80 \%$.

The lens arrays tested did not pass the Hail Ball Test which prevented implementation in the solar concentrator at this time.

The first molding trial of the Fresnel lens array mold was only intended to be the First Article. Parts molded were sent for testing but a second, and possibly third, molding of parquets should have proceeded before the mold was modified or rejected.

The use of 4 gates in the lens array mold requires that the flow of the 4 polymer streams must meet and knit in the center of the array to create a part without flaws. Parts were molded for approximately 4 or 5 hours and the molding parameters were adjusted to achieve the best parts obtainable in this relatively short time. Close inspection of some of the first parts molded revealed knit lines and some flow lines in the center of the lens array as one would expect. Although the parts sent to Sandia for testing were inspected closely for defects, the convergent Fresnel lenses made it difficult to inspect using a shadow graph and the facets and insert mating lines near the center of the array would tend to mask any fine knit lines in this area. Data from the impact testing of the lenses 
indicate that the knit and flow lines may be effecting the impact strength of the part. Unfortunately, the flaw was not spotted at the time.

The mold performed well for the first running and molded very high quality parts for the first operation. This is a credit to the design and construction completed by TRW as few molds of this complexity perform as well in their first operation.

\section{8) Recommendation for Future Work}

First, the parquet mold should be run again to see if the flow lines in the center of the lens can be removed by adjusting the molding conditions. The controls on the Incoe hot runner system should be adjusted to achieve the best possible parts from the mold. This would require at least 2 days of running time.

If the parquets do not pass impact testing after the second molding trials then other higher impact resistant PMMA resins should be considered for a third mold trial.

Considering more long term advances in this area of research we must realize that in the last 40 years most of the major advances in a given area have been achieved through incremental improvements in the materials used in these technological areas. The aircraft, automotive, electronics, appliance and even housing industries have all been transformed in the last 30 to 40 years through the implementation of new materials. For example materials used for photoresists, pin connectors, circuit boards, chip mounting blocks, magnetic disks all contribute to the function of modern electronics. Although scientists and engineers mentally visualize electronics as metal wires and silicon chips very little of the material in a modern computer is either metal or silicon.

Photovoltaic collectors will also require new advances in the materials to achieve cost effective electric power generation solutions. Currently there are basically three high performance optical plastics which are injection moldable, poly(oxycarbonyloxy1,4-phenylene-iso-propylidene-1,4-phenylene) [Bisphenol-A poly(carbonate), or "polycarbonate"], poly(methyl methacrylate) [PMMA or acrylic] and polystyrene. A number of copolymers and terpolymers of these monomers are on the market which also meet the low haze and birefringence requirements. However, the list is still relatively short. Some amorphous olefins can also be classed as a high performance optical plastics but currently the price of these materials restricts their application to smaller optical components of high value. Improvements in metallocene catalysist chemistry will reduce the cost of these polyolefins to pricing comparible to polycarbonates in the near future but we are as yet uncertain as to the impact resistance and notch impact strengths.

A number of thermal set materials such as poly(allyl diglycol carbonate) [ADC or PPG CR-39 $\left.{ }^{\mathrm{TM}}\right]$ are used in the ophthalmic industry. These materials require considerable time to crosslink ( 24 to $48 \mathrm{hr}$.) and have large shrinkages making it difficult to predict the dimensions of the finished optical part. Most of these resins are not economical for operations where resin mold's cost is high.

What is required for economical production of large optical components such as the Fresnel concentrator parquets is a material which allows the combination of the two technologies, injection molding and thermal set. Low viscosity monomers or prepolymers like those used for thermal set resins would allow the filling of large Fresnel 
molds ( 2 by 6 feet or greater). Fresnel lenses even with fine facets would not be a problem due to the resin low viscosity. The resin would quickly set allowing the lens array to be removed for the next cycle. This technology is called Reaction Injection Molding (RIM) ${ }^{1,2}$ and development began in the late 1960's. No RIM resin currently on the market is of optical quality. The main thrust of development in this area has been to synthesize resins capable of producing large structural components such as car body panels or bumpers.

Recently AOtec has experimented with a new optical RIM resin. We have been able to mold large optically clear parts ( 2 by 3 feet). These materials release easily from metals and therefore requires no mold release. The materials shrink very little during cure and cooling and therefore form optical quality surfaces. Physical testing has shown that these materials have high photostability, notch impact strengths, projectile impact strengths and low density. Optical testing has shown high transmittance (>90\%), a refractive index of 1.52 and low index dispersion. New materials such as this may allow the molding of large solar concentrator panels in a single shot. Cycle times would be slightly longer than the smaller 4 lens parquets but the RIM panels could easily have as many as 32 lens elements. This would reduce the time required to produce a single lens element when compared to injection molding. The initial costs of RIM equipment required to mold large structures is less than injection molding due to the lower pressures required. These factors should reduce the cost of a single lens element in the array. The new process would also reduce the complexity of the final assembly into the solar collector which may also further reduce costs.

Materials play an important role in the design and construction of the optical inserts. The process that was used in this report was less than perfect. Two developments may provide easier methods of optical insert construction. Hard copper and aluminum alloys have been developed. These materials can be diamond turned directly eliminating the need for electroplating of the insert. Although they are not as hard as the stainless steel they could be diamond turned again as required.

The cost of the precision diamond turning lathes and the quality of the machines has been improved since this project began. A facility molding a large number of Fresnel lenses could afford to construct and maintain the optical inserts with their own lathe where previously they were required to rely on an outside vender.

Another process which could be used is nickel replication. An insert could be constructed and then replicated using a nickel electrodeposition or vapor deposition techniques. This would reduce the cost of the inserts and allow the easy replacement of damaged inserts. The electrodeposition technique is reportedly being used for constructing injection mold inserts of ophthalmic quality. The vapor deposition technique has demonstrated the ability to replicate fine detail on a mold master for very large mold inserts ( 3 by 6 feet) ${ }^{3}$.

1 W.E. Becker ed., Reaction Injection Molding. Van Nostrand Reinhold Co. Inc., New York. 1979.

2 L.T. Manzione, "Reaction Injection Molding", Page 72 Volume 14 Encyclodedia of Polymer Science and Technology.

3 Weber Manufacturing Limited Hwy 12 P.O. Box 399 Midland Ontario LAR 4L1. 
These new materials and methods should be considered for further improvements of the Fresnel lens parquets.

\section{9) Cost Analysis}

Using the information obtained from the molding of the four lens parquet we developed new cost estimates for production lots and individual parts. We used industry standard machine rates for the molding of the pieces and standard wage and overhead rates for the New England area in calculating the cost of secondary operations. The list below give some of the costs used in the calculation. The ICI CP-82 OG PMMA pricing was used in the calculation although this material may not be acceptable for production due to its low inpact resistance.

Material Costs
\begin{tabular}{|l|l|}
\hline Dimension of Fresnel Lens Element & $17.22 \mathrm{~cm}$ sq. (6.78 in. \\
sq.) \\
Dimension of 4 Lens Parquet & $0.34 \mathrm{~m} \mathrm{sq.}(0.12 \mathrm{sq} . \mathrm{m})$ \\
(Optical area) & \\
Number of Parquets in 100,000 sq. m & 842723 \\
Mass of Parquet & $701.5 \mathrm{~g}(1.55 \mathrm{lb})$ \\
Molding Cycle Time & $71 \mathrm{~s}$ \\
& \\
Material & ICI CP-82 OG PMMA \\
Cost & $\$ 3.27 / \mathrm{kg}(\$ 1.48 / \mathrm{lb})$. \\
Cost per Lens & $\$ 2.29$ \\
Packaging & est. $\$ 10 / 100$ \\
\hline
\end{tabular}

Process Requirements
\begin{tabular}{|l|l|}
\hline Machine Requirements & 1000 US. ton molding machine @ \\
\$75 per Hr. & \\
Secondary Equipment & $\begin{array}{l}\text { - Drill press for removal of center } \\
\text { sprues } \\
\text { - Hopper dryer for drying of } \\
\text { PMMA resin } \\
\text { - Mold temperature control unit } \\
\text { - Incoe hot tip/runner control unit } \\
\text { - Mold vacuum pump }\end{array}$ \\
\hline
\end{tabular}


Pricing for 10,000,50,000,100,000, 200,000 and 842723 units are calculated in Table 9.1. The unit price ranges from $\$ 6.649$ to $\$ 6.455$. This pricing compares favourably with the estimates in the 1986 report (Sandia Contract No. 52-7481) for a four lens array. Prices in this report were estimated using 8.0 sq. in. lens elements prior to the design of the Fresnel collectors or the mounting fixtures. Current array costs are slightly less than predicted, but the cost per square meter of lens area is slightly greater than predicted in 1986. 
Table 9.1 Fresnel Solar Concentrator: Prices Based on Competitive Machine Rates

\begin{tabular}{|c|c|c|c|c|c|c|c|c|c|c|c|c|}
\hline Item & Qty & $\begin{array}{l}\text { Rate/Hr. } \\
\text { Molding }\end{array}$ & $\begin{array}{c}\text { Machine } \\
\text { Cost } \\
\text { Time (\$) }\end{array}$ & $\begin{array}{c}\text { Start Up } \\
\text { Cost } \\
\$ 1200\end{array}$ & $\begin{array}{l}\text { Matcrial } \\
\text { Cost (\$) }\end{array}$ & $\begin{array}{c}\text { Total } \\
\text { Cost (\$) }\end{array}$ & $\begin{array}{l}\text { Cycle } \\
\text { (Sec.) }\end{array}$ & Yield & $\begin{array}{l}\text { No. of } \\
\text { Cavities }\end{array}$ & $\begin{array}{c}\text { Avg. } \\
\text { Unit } \\
\text { Price } \\
(\$) \\
\end{array}$ & $\begin{array}{c}\text { Gross } \\
\text { Margin }\end{array}$ & Lot \\
\hline Lens & 10,000 & $\$ 75$ & 1.58 & 0.120 & 2.2912 & 3.9893 & 71 & $94 \%$ & 1 & 6.649 & $40.0 \%$ & $\$ 66,488$ \\
\hline \multirow[t]{4}{*}{ Parq. } & 50,000 & $\$ 75$ & 1.58 & 0.024 & 2.2912 & 3.8933 & 71 & $94 \%$ & 1 & 6.489 & $40.0 \%$ & $\$ 324,440$ \\
\hline & 100,000 & $\$ 75$ & 1.58 & 0.012 & 2.2912 & 3.8813 & 71 & $94 \%$ & 1 & 6.469 & $40.0 \%$ & $\$ 646,880$ \\
\hline & 200,000 & $\$ 75$ & 1.58 & 0.006 & 2.2912 & 3.8753 & 71 & $94 \%$ & 1 & 6.459 & $40.0 \%$ & $\$ 1,291,759$ \\
\hline & 842723 & $\$ 75$ & $\begin{array}{c}1.58 \\
\text { (yitlded) }\end{array}$ & 0.001 & 2.2912 & 3.8728 & 71 & $94 \%$ & 1 & 6.455 & $40.0 \%$ & $\$ 5.439 .777$ \\
\hline
\end{tabular}

${ }^{*}$ Requires 1000 ton Press 
Appendix I, List Subvenders and Codevelopers.

Resin Material

PMMA

ICI (Imperial Chemical Inc.) Acrylics Inc.

10091 Manchester Road

St Louis MO 63122 U.S.A.

800-325-9577

Mold Construction

TRW Fastners

180 State Rd. East Rt.2A

Westminster MA

01473

508-874-0151

508-874-2984 Fax

Parquet Testing

Solar Kinetics Inc. (SKI)

10635 King William Dr.

Dallas TX

075220

214-556-2376

Fresnel Lens Software

James Associates

and Design

7329 Meadow Court

Bolder CO.

80301

Tel. (303)-530-9014

Precision Optics Corporation

22 East Broadway

Gardener MA

01440

Diamond Turning

New England Diamond Turning (Contraves)

164 Locke Drive

Marlborough MA

01752-1186

Tel: 508-480-9643

Fax: 508-480-9226

OFC (Optical Filter Corp.)

69 Island St. Keene N.H.

603-357-7662 
Molding Ass.

Pro Corporation

296 Nanotuck St.

Florence MA.

Tel: (413)-584-1780 
Distribution:

MS-0899

MS-0619

Technical Library

Print Media

Org. 13414 (5)

Org. 12615

MS-0100

MS-9018

Document Processing for DOE /OSTI (2)

Central Technical Files

Org. 8523-2

MS-0752

MS-0752

M. Tatro

A. Maish (5)

MS-0753

Mr. Eric Peters (3)

C. Cameron

AOtec

14 Mechanic Street

Southbridge, MA 01550

Mr. Gus Hutchison

Solar Kinetics, Inc.

10635 King William Drive

Dallas, TX 75220

Mr. Edward Schmidt

Alpha Solarco, Inc.

510 East University Drive

Phoenix, AZ 85004

Mr. Vahan Garboushian

Mr. Robert Hoffman

Amonix, Inc.

3425 Fujita Street

Torrance, CA 90505

Midway Laboratories

2255 East 75th Street

Suite 303

Chicago, IL 60649 